\title{
Revitalization of the Novel of the Fire Smoke Cloud By Korrie Layun Rampan (Antropolinguistic Study)
}

\author{
Fajarika Ramadania ${ }^{1}$, Haris Supratno ${ }^{2}$, Setya Yuwana ${ }^{3}$, Suhartono ${ }^{4}$, Darni ${ }^{5}$, Udjang Pairin ${ }^{6}$ \\ 1,2,3,4,5,6Universitas Negeri Surabaya, Indonesia \\ Email: fajarika.19016@mhs.unesa.ac.id, harissupratno@unesa.ac.id, setyayuwana@unesa.ac.id, \\ suhartono@unesa.ac.id, darni@unesa.ac.id, udjangjw@unesa.ac.id
}

\section{Abstract:}

The revitalization of Api Awan Asap Novel by Korrie Layun Rampan (Anthropology Study), This study aims to (1) describe language, (2) describe technological systems, (3) describe livelihoods, (4) describe arts, and (5) describe systems religion in the novel Api Cloud Asap by Korrie Layun Rampan. The method in this study uses a descriptive analysis method and an anthropological approach that includes aspects of literary anthropology. The data source in this study is the novel Api Awan Asap by Korrie Layun Rampan. The collection technique in this research is text observation technique and interpretive descriptive technique. The results of this study can be concluded as follows: (1) the language system contained in the Api Awan Asap novel, namely the Dayak Benuaq language and English, (2) the technological system described in the Api Awan Asap novel such as: lou, bivouac, ulin, ketinting, sharp weapons, ulap, ulap doyo, jewelry, (3) the livelihood system described in the novel Api Awan Asap, such as gardening, hunting, berhuma, cutting down forests, and businessmen, (4) the arts described in the novel Api Awan Asap, namely musical instruments, sculpting, weaving, dancing, singing, and weaving, (5) the religious system described in the novel Api Awan Asap, namely the application ceremony, wedding ceremony, magic, legend, and customary law ceremonies.

Keywords:

Revitalization; novel; literary anthropology

\section{Introduction}

Literature is an art that questions life, while life itself is very broad. Good writers will try to approach this life so that their works are truly meaningful to their readers. The literary work appears through the imagination and reason of human creativity which is wrapped in a writing that contains the value of life for humans. One form of literary work that is wrapped in a writing is a novel. The science that studies the relationship between language and culture is called linguistic anthropology which was pioneered by Franz Boas, while in parts of Europe the term ethnolinguistics is used (Duranti, 1997, p.1-2). Basically, anthropolinguistics, ethnolinguistics, and cultural linguistics in general have something in common (Duranti, 1997, p.9). The anthropolinguistic approach seeks to examine what people do with the language and utterances produced, the gestures associated with the context in which they appear. Sibarani (2006, p.12) details the things observed in anthropolinguistics, namely: 1) analyzing cultural terms and expressions; 2) analyze the naming process; 3) analyzing politeness; 4) analyze the cultural concept of language elements; 5) analyze ethnicity from the point of view of language; and 6) analyze the way of thinking through the structure of language.

The novel Api Awan Asap by Korrie Layun Rampan is a prose work that tells of a local wisdom of the Dayak Benuaq people of East Kalimantan which takes pictures of the background of a culture and the habits of the local community to fulfill their needs in preserving an environment, as lou is also a heritage and traditions to be preserved. Lou or 


\section{Lakhomi Journal: Scientific Journal of Culture \\ ISSN: 2774-311X (Online), 2774-4728 (Print)}

Vol. 2, No. 3, September 2021, Page: 109-124

Email: lakhomijournal@gmail.com

long house built on the ground rising facing the rising sun. The large ironwood poles are carried by the locals from the forest slightly to the land, the wooden docks are placed like train tracks, the ironwood trees which are the size of an adult human can easily be pulled by dozens of men and women working together.

The main stake was built in the middle of the lou, it was as large as a giant tree erected as earth spikes. The corner pillars are also large ironwood trees, although they are smaller than the main pillars. The main pillars were carved with carvings of the origin of the lou creation by sculptors and nature painters who were obtained from ancestral myths. Lou was built not because people couldn't afford to build their own houses, but it was built because tradition teaches that living together gives greater benefits than the way of life of individuals who only care about themselves. Lou is used as the residence of the Benuaq Dayak community and is used to carry out all traditional activities that have been taught by their ancestors such as traditional ceremonies.

Lou residents can also carry out activities that allow traditions to be preserved from generation to generation, such as women weaving mats, bags, wallets, kitchen utensils and children's toys. The activity of weaving cloth using doyo leaf fibers is also occupied by women. All of these activities are based on the teachings that were taught by their ancestors. Not only that in the novel there is also a legend about the occurrence of a lake and magical elements typical of the Benuaq tribe that made the hairs stand on end, in which there was a hole in the hole that made a girl named Pune fall while carrying buffalo blood for her mother's wedding ceremony., in that strange hole his feet felt held from under the hole. People thought that the one who grabbed Pune's leg was the ghost of the land, but after the crowd pulled Pune from the landslide, suddenly someone appeared like an ancient human to the surface of the ground. His body was pale white because he had never been exposed to the sun, his hair was long past his heels and his eyes were slanted. No one can identify that the land man who was mistaken for a ghost is Jue, the husband of Nori and the father of Pune who had been missing for twenty years.

Hammar (2017: 108-109) expressed his opinion as follows. Local wisdom is a view of life and knowledge as well as life strategies in the form of activities carried out by local communities in answering various problems in meeting their needs. This term in English is conceptualized as local wisdom (local policy) or local knowledge (local knowledge) or local genious (local intelligence). The system for meeting their needs covers all elements of religious life, science, economy, technology, social organization, language and communication as well as the arts.

Ratna (2011: 91-92) Local wisdom, according to other understandings, is often confused with local culture (local culture). Besides that, another term that often arises is local knowledge. By definition, both local wisdom and local knowledge are clearly part of local culture. Local wisdom and local knowledge are only a small part of the essence of the habits of certain community groups. Local wisdom has universal characteristics in the sense that these phenomena are present in various communities, even though they are expressed in different languages. As a cultural heritage, local wisdom needs to be maintained and preserved.

Local wisdom is the wisdom or original knowledge of a community that comes from the noble value of cultural traditions to regulate the order of people's lives. Local wisdom can also be defined as local cultural values that can be utilized to regulate the order of people's 
lives wisely or wisely. Local wisdom belongs to the community whose attitude and personality are mature to be able to develop local potential and resources in making changes for the better. According to Apriyanto (2008: 59) local wisdom is a variety of values that are created, developed and maintained by the people who guide them in their lives. (Sembiring, A. et al. 2019)

Regarding local wisdom, there are several types of research that have been carried out by previous researchers.Previous researchers have researched local wisdom in their research, but the research conducted by researchers now certainly has differences. Following up on this, previous researchers can be used as reference material in research that will be carried out at this time.

\section{Research Methods}

The method used in this study uses qualitative methods. This descriptive qualitative type means data that is broken down in words or pictures, not in the form of numbers (Semi, 2012: 30). The method is used as a way to solve problems or answer all the problems to be studied starting from collecting, compiling data to the stage of analyzing data.

\section{Result and Discussion}

\subsection{Language}

Language is the ability of humans to communicate with humans in order to establish a good relationship between people. Language is also a means of communication to establish a relationship with other people. The language in Korrie Layun Rampan's novel Api Awan Asap generally uses Indonesian but also uses two languages, namely Dayak Benuaq (regional language) and a little (foreign language) English.

a. Benuaq Dayak language

1. Lou : Dayak long house (BHS/bdb, 2015: 7)

2. Purchase: the shaman and the ceremony performed by the shaman (BHS/bdb, 2015: 8)

3. As big as : a supernatural figure who is an expert in deciding the problem of theft (BHS/bdb, 2015: 32)

4. Belontakng: wooden statue (ulin) where the buffalo is tied as a sacrifice (BHS/BDB, 2015: 2)

5. top brass : position as high as village head (BHS/bdb, 2015: 7)

6. Stupid: cheerful music (BHS/bdb, 2015: 5)

7. Bivouac : emergency building (BHS/bdb,2015: 7)

8. Ketinting: small boat powered by engine (BHS/bdb, 2015: 39)

9. Magic : a midi skirt-like fabric split at the back, special clothing for women (BHS/BDB, 2015: 117)

10. Doyo: traditional woven fabric using doyo shrub fiber (BHS/BDB, 2015: 117)

11. Doyo: a type of shrub whose leaf fibers can be threaded and then woven into a cloth that is characteristic of the Dayak Benuaq (BHS/bdb, 2015: 79)

12. sahukng: caping whose material is taken from blue palas leaves (BHS/bdb, 2015: 29)

13. Continent: circle of area controlled by lou and is the center of the village (BHS/bdb, 2015: 30)

14. continent : one of the Dayak tribes who inhabit the interior of Kutai district, East Kalimantan, especially in Melak District, Lawa District, Penyinggahan District, Muara Muntai District, Muara Pahu District, and Tenggarong District (BHS/BDB, 2015: 31) 
15. Keramuq : a type of fruit that is ripened by simply dousing it with hot water, the taste of the flesh is sweet and sour, the fruit is like fruit melnjo, when ripe it is dark brown (BHS/bdb, 2015: 31)

16. recipe: a type of rambutan fruit (BHS/bdb, 2015: 31)

17. Siwo: a type of rambutan fruit (BHS/bdb, 2015: 31)

18. lai : Durian (BHS/bdb, 2015: 31)

19. flood-hood: a log entrepreneur with a system of waiting for flood waters to come, new logs can be washed into rivers (BHS/bdb, 2015: 128)

20. Burden: a plant that usually grows on the shores of a lake (BHS/bdb, 2015: 44)

21. Peraro: the tree is tall, the fruit is delicious to eat because it contains oil such as peanuts. Cooking it can be rubbed or fried (BHS/bdb, 2015: 44)

22. Tauke : financiers, shop owners, rich people under a few conglomerates (BHS/bdb, 2015: 108)

23. Katung: a tool for carrying children, which are generally made of wooden buttresses and decorated with carved bead embroidery (BHS/BDB, 2015: 118)

24. busy : busy (BHS/bdb, 2015: 158)

25. Kewengkey : funeral ceremony for the bones of the ancestors and lou's family (BHS/bdb, 2015: 82)

26. Nalitn link : the year cleaning ceremony, namely thanking God for preserving the harvest and season (BHS/bdb, 2015: 82)

27. When : a typical Dayak Benuaq date board that uses 29 . calculations days for February and 30 days for other months, the calendar is also included about good days, good months, sustenance, types of game animals, and natural signs that refer to good or bad predictions, a year is counted as 12 months. (BHS/bdb, 2015: 103)

28. Nayau : beheading (BHS/bdb, 2015: 110)

29. Lading: kitchen knife (BHS/BDB, 2015: 117)

30. Fast: a kind of cauldron (BHS/bdb, 2015: 117)

31. Linga: a kind of sickle, but using a short head (BHS/bdb, 2015: 118)

32. Kaman : a tool to clean up the remains of leaves and pieces of wood in huma or gardens (BHS/bdb, 2015: 118)

33. can : a rice seed storage device that is worn on the waist when harvesting (planting rice in the field) (BHS/bdb, 2015: 118)

34. Gamak: basket where rice is harvested using ani-ani (BHS/bdb, 2015: 118)

35. Tumpi : snacks, traditional Dayak cakes (BHS/bdb, 2015: 133)

36. Aper: leaves and flowers that belian holds as a means of ceremony (BHS/bdb, 2015: 153)

37. Elastic: explode (BHS/bdb, 2015: 155)

38. Tamenrikukng: the god who created the earth (BHS/bdb, 2015: 167)

39. Tony; god of the caretaker of the land (BHS/bdb, 2015: 167)

40. Uwok: ghost (BHS/bdb, 2015:167)

\section{b. English}

1. speed boat: a type of water boat with a modern engine (BHS/bi, 2015: 49)

2. Life beigns at forty: life just begins at forty

3. Make up: make-up (BHS/bi, 2015: 119)

4. Land clearing : clearing of new land (BHS/bi, 2015: 130)

\subsection{Technology System}

Technological systems are the development and application of tools, machines, and materials used by the community for the purposes of life. 
The technological systems contained in the novel Api Awan Asap by Korrie Layun Rampan include, lou, bivouac, ulin, ketinting, and sharp weapons technology systems, ulap, ulap doyo, jewelry, kitchen utensils, betel nut, jars, linga, kamau, bisan, gamak, cotton, white mini bowl, food, merchant ship, canoe, speed boad, sailing ship, and camera.

a. Lou

Lou is a longhouse of the Benuaq Dayak tribe that is used as a place to live.

\section{Quote 1}

Lou was built not because people couldn't afford to build their own houses, but it was built because tradition teaches that living together gives greater benefits than the way of life of individuals who only care about themselves. In lou, every citizen can directly communicate at any time, so that all difficulties can be shared and known to other residents. (ST/11, 2015: 27).

Related to quote 1 above, it explains that the Lou was built by local residents, it doesn't mean they can't build their own houses, it's just that Lou was built so that tradition is maintained, in Lou, residents can communicate at any time, so that if they experience difficulties, these difficulties can be overcome. overcome together. It is the tradition that teaches them that living together gives such great benefits.

\section{b. Bivouac}

Bivouac is an emergency building that is usually used by residents as a place to stay or temporary rest.

\section{Quote 2}

After deliberation with the local residents, the Jepi officials brought all their residents down the Namuk River and finally arrived at the Nyawatan River. In an area deemed suitable, bivouacs were erected and laid out for temporary accommodation (ST/bvk1, 2015: 7-8).

Based on quote 2 above, it is clear that local residents moved from the old village to the new village. After the Jepi officials consulted with the local residents, the Jepi officials brought all their citizens down the Namuk River and finally they arrived at the Nyawatan River. They arrived at a suitable area, built a bivouac and laid it out for a temporary rest. The elders knew that the name of the place on the banks of the Nyawatan river was Dempar, so he decided that the name was Dempar Village, which is now the new village for the Dayak Benuaq to live and build a lou.

\section{c. Ulin}

Ironwood is a strong iron wood, ironwood is a typical plant of Kalimantan which is often used as a building material such as materials for making houses, bridges, and even equipment related to the kitchen.

\section{3 quote}

The large ironwood pole was carried by residents from the forest a little ashore. By placing wooden docks like railroad tracks, ironwood trees that are the size of an adult human are easily pulled by dozens of men and women working together. The main stake was built in the middle of the lou, it was enormous, like a giant tree erected as earth spikes. The corner poles are also large ironwood trees, although they are smaller than the main poles (ST/uln1, 2015: 8). 
Based on quote 3 above, it is clear that ironwood is the main ingredient in building the lou or long house that they just built in the village of Dempar. The ironwood is carried by residents from the forest somewhat ashore. The ironwood tree is pulled by men and women together. In the quote it is very clear that ironwood is needed in building the lou or longhouse of the Benuaq Dayak people because ironwood is a very strong wood so it is suitable for making lou.

\section{d. Crab}

Ketinting is a small boat with an engine as a means of transportation in the interior, in Korrie Layun Rampan's novel Api Awan Asap ketinting is used as a means of transportation.

\section{Quote 4}

At that time there was absolutely no land connection to Samarinda, because there was no land route. The only transportation is a commercial ship, which sometimes takes two or three weeks to arrive in the sub-district capital. From there it took two days with a lot of excitement before arriving at Lou Ulu (ST/kttg1, 2015: 93-94).

Based on quote 4 above, it explains the use of ketinting is used as a means of transportation because there is absolutely no land connection to Samarinda, because there is no road so the only way is to use water transportation. So from there it also takes time with ketinting, because ketinting is a small boat that is given an engine to carry it to Lou Ulu.

\section{e. Sharp Weapons}

Sharp weapons are tools used to help human needs such as cutting tools, to killing tools.

\section{5 quote}

And if any of the residents of the lou wake up from sleep when the headhunters attack spears and chopsticks can be launched from above to ward off people with bad intentions (ST/st1, 2015: 38).

Based on quote 5 above, it explains that the use of sharp weapons such as spears and chopsticks will be launched if there are people who will have evil intentions against the people of Lou.

f. Magic

Magic is a kind of fabric midi skirt split at the back, a special clothing for women.

\section{Quote 6}

...are included with ulap cloth and doyo ulap which were specially prepared for the application event (ST/ulp1, 2015: 117).

Based on quote 6 above, it explains that the use of ulap is also found in the Api Awan Asap novel because ulap is a kind of midi skirt specifically for women, which is used as a condition for Nori's marriage proposal given by Sakatn.

\section{g. Doyo's Snake}

Doyois a cloth that is woven traditionally using doyo shrub fiber. Doyo ulap cloth is also included in the terms of Nori's application given by Sakatn. Seen in quote 7 below: 


\section{7 quote}

...Ulap cloth and doyo ulap are included which are specially prepared for the application event (ST/ud1, 2015: 117).

\section{h. Jewelry}

Jewelry is an object that is used to make up or beautify oneself. A discussion of the use of jewelry can be seen from quote 9 below:

\section{8 quote}

'There are anklets, bracelets, rings, earrings, safety pins and hair pins. Usually, all of the jewelry equipment is made of twenty-four carat gold, because as a condition of application, all materials must be original, not mixed or imitation (ST/phsn1, 2015: 117).

Based on quote 8 above, it is explained that the conditions for the application include jewelry such as anklets, bracelets, rings that will adorn the fingers, earrings, chests and hairpins to support appearance. The jewelery is finely made of real gold weighing twenty four carats.

\section{i. Kitchen Appliances}

Kitchen utensils are tools used for cooking activities, but in Korrie Layun Rampan's novel Api Awan Asap, kitchen utensils are used as a condition for Nori's application. A discussion of kitchen utensils can be seen in quote 9 below:

\section{9 quote}

'It also includes kitchen utensils such as freshly forged lading, along with rice spoons and vegetable spoons which are all made of ironwood, copper kenceng, and a set of antique bowls and plates placed in high-legged copper trays (ST/pd1, 2015: 117).

Based on quote 9 above, the conditions for Nori's application are accompanied by kitchen utensils such as lading, rice spoon, vegetable spoon, copper kenceng, a set of antique bowls and plates.

\section{j. Chewing Equipment}

Betel nut is a tool used for betel nut, usually in the form of a spittoon to spit betel gum in the mouth, a mortar to crush materials and a mortar as a betel pulverizer.

\section{0 quote}

'A low spittoon for chewing is also included and a silver grinder complete with mortar and pestle (ST/pm1, 2015: 117).

Related to quote 10 above in Korrie Layun Rampan's novel Api Awan Asap, there are also tools for betel nut as a condition of application, such as a spittoon, which is a tool for spitting betel remains in the mouth and a silver chopper complete with mortar and pestle.

\section{k. Urn}

The jar is one of the accessories or a place that is used to fill an object. Regarding the discussion of jars, it can be seen from quote 11 below:

\section{Quote 11}

'...the jar is a symbol of filling water and rice for the family (ST/gc1, 2015: 118). 
Based on quote 11 above in the novel Api Awan Asap by Korrie Layun Rampan, it is explained that the jar is also in the application requirements, because it is a place for filling water and family rice which can later be used after marriage.

\section{Human Equipment}

Huma equipment is also mentioned in Nori's application requirements such as the linga, which is a sickle-like tool but uses a short upstream and the kamau is a tool for cleaning up leftover leaves and pieces of wood in the huma or in the garden. worn on the waist when cooking or planting rice, and gamak is a place for rice to be harvested using ani-ani. The following quotes about human equipment can be seen in quote 12 as follows:

\section{2 quote}

There are also linga and kamau which are usually used by women to weed rice. There are bisan and gamak...(ST/pb1, 2015: 118).

\section{m. Katung}

Katung is a tool for carrying children which is generally made of wooden slats and decorated with carved bead embroidery. The discussion about cotton can be seen from quote 13 below:

\section{3 quote}

'... here's a bag wrapped with a series of beads in the form of a picture depicting a baby laughing at the world (ST/ktg1, 2015: 118).

Based on quote 13 above, it is explained that in the conditions of application there is also a cotton bag, which is a tool that functions as a means of carrying a baby which is placed on the back of the father or mother which is generally made of wooden buttresses decorated with bead embroidery. Katung can be used when Nori and Sakant already have a baby.

\section{n. White Mini Bowl}

The white mini bowl is a small white bowl. In Korrie Layun Rampan's novel Api Awan Asap, it is explained that this bowl is used as part of the tradition of proposals. Quotes that discuss white mini bowls can be seen in quote 14 as follows:

\section{4 quote}

Another thing is a white mini bowl as a substitute for the tongue of the applicant's family to convey the words of application (ST/mmp1, 2015: 118).

Based on quote 14 above, it is explained that the white mini bowl is also provided by Sakatn at the application ceremony because it is a substitute for the tongue of the applicant's family to convey the words of application.

\section{o. Food}

Food is food that is usually consumed by a person as a source of energy. Regarding solid food, see excerpt 16 below:

\section{5 quote}

'On the stretch of the lou veranda, copper trays will be arranged in long rows. On top of the trays, antique plates are arranged that contain a certain number of snacks such as tumpi and special lemang which are steamed in bamboo (ST/mkn1, 2015: 133). 
Based on quote 15 above, it explains that on the lou stretch, a copper tray will be arranged lengthwise which contains typical Dayak Benuaq foods such as tumpi and lemang which are cooked by steaming in bamboo and served on antique plates.

\section{p. Commercial Ship}

Trading ship or merchant ship is a ship that specifically transports merchandise. The discussion regarding the use of commercial vessels is as follows:

\section{6 quote}

'At that time there was absolutely no land connection to Samarinda, because there was no road. The only transportation is a commercial ship which sometimes only takes two or three weeks to arrive in the sub-district capital (ST/kn1, 2015: 93).

Based on quote 16 above, it explains that at that time there was absolutely no land connection to the city of Samarinda, so the only way was to use water transportation such as commercial ships or ships which were usually specifically used to transport merchandise which sometimes took two or three weeks to arrive. in the district capital.

\section{q. Canoe}

A canoe is a small and narrow boat, which is usually driven by a human being driven by a paddle. A discussion of canoes can be seen in quote 17 below:

\section{7 quote}

'Canoes and speed boats and sailing boats are the pleasures of travelers who want recreation (ST/kno1, 2015: 49).

Based on the quote 17 above, it describes that the canoe is also in the novel Api Awan Asap by Korrie Layun Rampan. Canoes are small boats that are used by tourists and include the pleasure of visitors who want to enjoy recreation in tourist places.

\section{r. Speed Boat}

Speed boat is an engine-powered ship that can go fast. A discussion of speed boats can be seen in quote 18 below:

\section{8 quote}

'Canoes and speed boats and sailing boats are the pleasures of travelers who want recreation (ST/sp1, 2015: 49).

Related to quote 18 above that speed boats are also included in the pleasure of visitors who want to enjoy recreation in tourist attractions.

\section{s. Sailing Ship}

Sailing ship is a ship that is driven by using a sail that utilizes wind power as a propulsion. The discussion regarding the use of sailing vessels is found in quote 19 as follows:

\section{9 quote}

'Canoes and speed boats and sailing boats are the pleasures of travelers who want recreation (ST/kl1, 2015: 49). 
Related to quote 19 above, it is said that sailing boats are also used as a tool used to enjoy recreation in tourist attractions. Based on quote 19 explains that canoes, speed boats and sailing boats are used as entertainment tools in enjoying the tourist attractions built by Nori.

\section{t. Camera}

The camera is a tool that can be used to record and capture an object in the form of photos and videos. Discussions regarding the use of cameras include some of the quotes below as follows:

\section{0 quote}

'cameras keep recording, and keep recording, capturing vintage and original images. The television reporter from the city of provence seemed very satisfied with the special interview. Cameramen also feel that the images they record really fulfill the desire for beauty $(\mathrm{ST} / \mathrm{kmr} 4$, 2015: 37).

Based on quote 20 above, it is explained that there were television reporters and cameramen who came to Lou to conduct interviews with Jepi officials and highlight and record everything in Lou's area.

\subsection{Livelihood System}

Livelihood is a job that supports human life to meet the needs of life. The livelihood system in the novel Api Awan Asap by Korrie Layun Rampan includes the following:

\section{a. Gardening}

Gardening is an ancestral culture that has been preserved for generations. Gardening is one of the activities carried out to be close to nature. Gardening is also a job that is occupied in meeting needs that produce high economic value. Related to the novel Api Awan Asap which was studied by researchers, the most dominant livelihood is a livelihood that is close to nature, namely gardening. Some quotes about gardening livelihoods can be seen in the following quote:

A year ago, Jepi officials stepped on Jakarta for the first time. According to experts in Jakarta, he has done something very beneficial for environmental sustainability. The village of Dempar that he built has not yet reached the age of twenty years, but has shown signs of steady development in the future in meeting all their needs related to plantation livelihoods (Gardening). It can be seen very clearly described in quote 21 below as follows:

\section{1 quote}

'Plawija lands, which in the early years were a commodity-producing area for the needs of the people, were converted into coffee plantations with higher economic value. Dempar became famous as a pilot village because it was successful in being self-sufficient. Not only daily commodities produced by Lou residents, but also plantation products such as rubber and rattan (SMP/brk2, 2015: 25).

Based on quote 21 above, it is explained that the secondary crops are converted into coffee plantations which have a higher economic value. Dempar village is also known as a pilot village because of its success in meeting all needs that are close to nature such as producing rubber and rattan plantations. 


\section{b. Hunting}

Hunting is also an activity of chasing, catching or killing wild animals to eat, even hunting is also done to get products such as leather, ivory, horns and so on. The hunting livelihood system carried out by the lou residents in the novel Api Awan Asap by Korrie Layun Rampan is carried out to obtain adequate food and nutritional needs for the residents. Regarding the hunting livelihood system, it can be seen in quote 22 below as follows:

\section{2 quote}

'Animals are hunted to the extent of their need for protein (SMP/brb1, 2015: 26).

\section{c. Humanity}

Berhuma or huma is a livelihood system that is also found in the novel Api Awan Asap by Korrie Layun Rampan. A discussion of the human livelihood system (huma) can be seen in quote 23 below:

\section{3 quote}

'Huma is the producer of rice and secondary crops for all the lou residents. Each resident has a certain area that has been designated as a human rights area (SIM/brh1, 2015: 31).

Related to quote 23 above, it is very clear that there is also a livelihood system carried out by the Lou residents to meet their daily needs.

\section{d. Cutting down the Forest}

The Lou people also live side by side with the forest, for example, they take advantage of forest resources such as tree trunks to meet their needs related to building materials, but the residents are smart in utilizing the forest. Seen in quote 24 below:

\section{4 quote}

'Forest trees may be cut down and taken to the extent of the residents' needs (SMP/mh1, 2015: 26).

\section{e. Entrepreneur}

An entrepreneur is a person who runs a business, both buying and selling business, as well as an effort to produce which has the main goal of making a profit. The following is a discussion of the entrepreneur as follows:

Nori also has a shop that she manages herself. Nori's shop is visited by many shoppers. They prefer to shop for necessities at Nori's shop rather than shopping at the subdistrict capital, because the goods sold by Nori are more affordable. Discussions related to entrepreneurs can be seen in quote 25 below as follows:

\section{5 quote}

'Some villages that are on a land route and a few more with waterways on the banks of the Nyawatan River prefer to buy from a Nori shop rather than having to shop in the sub-district capitals such as Damai, Melak, Barong Tongkok, or Long Iram. Not only because the road to get there is a bit difficult, but also because Nori's prices are sometimes even lower than those of shops in the sub-district town (SMP/pgsh2, 2015: 76). 
The tourism business is also found in the novel Api Awan Asap by Korrie Layun Rampan, because this business is an idea and the result of a business designed by Nori rhymes fifteen years ago, and now Nori can realize it and even this business is also Nori's livelihood system. The following discussion of the tourism business can be seen in quote 26 below:

\section{6 quote}

'Fifteen years ago Sakatn still couldn't believe what Nori had devised. However, when he was by the lake with Nori, the idea had become a reality. Indeed, not all of them can be built, but the main idea has been implemented. Several bungalows have been established and the beautiful gardens are very well laid out, the lakeside pier was designed by a natural architect who combines local elements with the strength of modern buildings. Canoes and speed boats and sailing boats are a pleasure for travelers who want recreation (SMP/pgsh3, 2015: 49).

\subsection{Art}

Art is one of the elements of culture or all human expressions that are full of beauty that can be enjoyed.

a. Musical Instruments

A musical instrument is a tool that is played by hitting, picking, blowing and so on to produce sounds. The musical instruments contained in the novel Api Awan Asap by Korrie Layun Rampan are gongs, bonangs and drums. The instrument was used at the time of Nori and Sakant's wedding ceremony. The following discussion of musical instruments can be seen in quote 27 below:

\section{7 quote}

'It's past the rising music. The sound of gongs and bonangs combined with the sound of drums is like being blown by the air that smells of wilderness (KSN/am1, 2015: 5).

\section{b. Sculpt}

Sculpting is a technique that forms objects by making hollows or protrusions that will form a certain pattern using a chisel, chisel or carving tool. The material used for carving is usually a hard object such as stone or wood. The element of art contained in the novel Api Awan Asap by Korrie Layun Rampan states that carving activities are also carried out by local residents so that their ancestral traditions are preserved. Regarding the discussion of sculpting, it can be seen from quote 28 below:

\section{8 quote}

'By sculptors and natural painters, the main pillars were carved with carvings of the origin of making lou which were obtained from ancestral myths. (KSN/mht1, 2015: 8).

\section{c. Weaving}

Weaving is an activity carried out by a community such as arranging crosswise blades or sheets or overlapping arranged blades or sheets usually in the form of bamboo, rattan, leaves or paper. Weaving activities are also carried out by Lou residents so that the tradition is maintained from generation to generation. The material used by the Benuaq Dayak community in this weaving is rattan. Rattan woven by the women in the lou also produces items that have artistic value such as weaving mats, bags, wallets, kitchen utensils and even toys. The following discussion of weaving activities can be seen in quote 29 below as follows: 


\section{9 quote}

'In the lou, residents can carry out all activities that allow traditions to be preserved from generation to generation. For example? You see, for example, the women weaving the mats. Weaving bags, wallets, various kitchen utensils, and children's toys (KSN/mym1, 2015: 28).

\section{d. Dancing and Singing}

Dancing and singing are activities that contain artistic value in order to preserve a tradition. As done by the young people in the novel Api Awan Asap by Korrie Layun Rampan, they practice dancing and singing at night in the lou. The following discussion of dancing and singing can be seen in the quote 30 below as follows:

\section{0 quote}

'In the evening young people can practice dancing and singing. In addition to buying events, dances are a type of art that is very popular. All of them were taken down without coercion (KSN/mdm1, 2015: 29-30).

e. Weaving

Weaving is the process of making fabrics made from yarn or leaf fibers. Weaving activities carried out by women using doyo leaf fibers are found in the novel Api Awan Asap by Korrie Layun Rampan. The following discussion of weaving activities can be seen in quote 31 as follows:

\section{Quote 31}

'Besides that, women also work on traditional weaving using doyo leaf fiber (KSN/Mnn1, 2015: 28).

\subsection{Religious System}

Religious system is a religious system is a belief and belief of society. Religious systems usually include all beliefs held by society or groups. It is this belief that makes them hold fast to beliefs, such as religious beliefs that come from God, traditional cultural beliefs that come from their ancestors such as rituals and even myths that are believed by the community itself.

\section{a. Application Ceremony}

The proposal ceremony is an event that must exist before the wedding ceremony. Regarding the discussion of the application ceremony can be seen in quote 32 below:

\section{2 quote}

'The incident that surprised Nori was the arrival of a customary application from Sakatn which was conveyed by the envoy of Sakatn's parents to the Jepi officials (SR/ul1, 2015: 115).

\section{b. Wedding Ceremony}

The wedding ceremony is a traditional ceremony held in order to welcome the wedding event. The wedding ceremony is important for humans because the wedding ceremony is an activity that must be sacred and remembered so that it needs to exist. Regarding the discussion of the wedding ceremony, see quote 33 below:

\section{3 quote}

'In the giant plate indeed pooled the blood of buffalo. Just finished the buffalo spearing ceremony in Belontakng. And now the blood is the last ceremony of blessing the marriage of the daughter of Jepi's top brass. 
"With just one smear of buffalo blood on the bride's forehead, the marriage blessing will be completed (SR/up1, 2015: 1-2).

Based on quote 33 above, it is explained that Nori and Sankatn's wedding ceremony was carried out by spearing a buffalo and only one time smearing buffalo blood on the bride's head, then the wedding ceremony has been completed.

c. Magic

Magic is a magical power that contains magical elements in it. There is magic at the time of Nori and Sakatn's wedding ceremony. That time when Pune screamed for help because his leg got stuck in a hole, when he brought the blood of a buffalo which would be a condition for his mother's legal marriage. all the residents who were present at the ceremony simultaneously wanted to help, but suddenly they seemed to be bewitched. Based on the description above, it can be seen in quote 34 below:

\section{4 quote}

'Everyone present simultaneously wanted to help. But they all suddenly seemed to be bewitched, their bodies seemed to be bound and bound with strong ropes. Until simultaneously in that place a quiet and quiet silence was created (SR/shr1, 2015: 6).

\section{d. Legend}

Legend is a traditional story that local people believe about events that are considered true. The legend contained in the novel Api Awan Asap by Korrie Layun Rampan is about a story about Lake Beluq, which is a unique lake and has a legend that makes no sense due to the disappearance of three foreign researchers, in a lake inhabited by a giant dragon, there are also which says that lake researchers were lost because they were deliberately picked up by spirits, to the story of a cursed lake. The following discussion of the legend contained in the novel Api Awan Asap by Korrie Layun Rampan can be seen in the quote 35 below as follows:

\section{5 quote}

'The villagers in the north think the lake is haunted. Even after the Japanese experts drowned there, no one dared approach the lake, let alone fish or fetch water. There are a number of people who say that the lake is inhabited by a giant dragon that will prey on anyone who disturbs its residential palace (SR/lgd1, 2015: 42). Beluq lake.

Excerpt 35 about the legend tells a legend about the origin of a unique lake called

\section{e. Customary Law Ceremonies}

The customary law ceremony is a ceremony or part of the local community's rules that must be carried out. The ceremony in Korrie Layun Rampan's novel Api Awan Asap explains that in order to decide a problem that occurs such as theft, a ceremony is carried out by summoning an unseen person to solve the problem. The following about a traditional ceremony can be seen in quote 36 below:

\section{6 quote}

'If one of the lou residents confessed that the tree was his and took the fruit to sell? "There is a moral ethic that must be adhered to. If the part that has been determined as common property, it must be recognized and accepted as customary rules govern it. So, all citizens are subject to 
custom? Yes, because all the slightest violations will make the citizens feel ashamed. That shame cannot be paid for with money. Except the redemption ceremony! Ceremony? yes. if a person steals, the custom regarding the law of stealing must be decided. Must be called Seieng Besara, namely supernatural figures who are experts in deciding matters of theft! (SR/uha1, 2015: 32).

\section{Conclusion}

Based on the results of the analysis of local wisdom in the novel Api Awan Asap by Korrie Layun Rampan from the anthropological elements of language, technology systems, livelihood systems, arts and religious systems, it can be concluded as follows:

1. Language

The general language found in the novel Api Awan Asap by Korrie Layun Rampan is Indonesian, but there are also two languages, namely Dayak Benua (regional language) and English (foreign language). Some of the Dayak Benuaq vocabularies contained in this study are, lou, belian, seingbesara, belontakng, high-ranking, buntakng, bivouac, ketinting, ulap, ulap doyo, doyo, sahukng, continent, subcontinent, keramuq, rekep, siwo, lai, flood hood, bemban, peraro, tauke, cotton, hibuk, kewengkey, nalitn link, when, ngayau, lading, kenceng, linga, kamau, bisan, gamak, tumpi, aper, bingkas, tamenrikukng, tonoy, and uwok. And some English vocabulary such as: speed boat, life beigns at forty, make up, and land clearing.

2. Technology System

The technological system found in the novel Api Awan Asap by Korrie Layun Rampan is explained about several tools that exist and are used in the novel, including: lou, bivouac, ironwood, sharp weapons, ulap, doyo ulap, jewelry, kitchen utensils, utensils betel nut, jars, berhuma equipment, cotton balls, white mini bowls, food, merchant ships, canoes, speed boats, sailing boats, and cameras.

3. Livelihood System

The livelihood system found in the novel Api Awan Asap by Korrie Layun Rampan describes livelihood as a job that supports human life to meet the needs of life which includes gardening, hunting, housing, cutting down forests, and entrepreneurs.

4. Art

The art found in the novel Api Awan Asap by Korrie Layun Rampan is explained about art as an element of culture or all human expressions full of beauty that can be enjoyed, which includes musical instruments, sculpting, weaving, dancing and singing, and weaving.

5. Religious System

The religious system found in the novel Api Awan Asap by Korrie Layun Rampan explains the religious system as a belief believed by the community or group which includes a religious system, namely, proposal ceremonies, marriage ceremonies, magic, legends, and customary law ceremonies.

\section{References}

Duranti, A.(1997). Linguistics Antropology. Cambridge: Cambridge University Press.

Endraswara, Suwardi. (2013). Metode Penelitian Sastra: Epistemologi, Model, Teori, Dan Aplikasi. Yogyakarta: CAPS (Center of Academic Publishing service).

Foley, W.A. (1997). Antropological Linguistics: An Introduction. Oxford: Blackwell Published.

Halliday, M.A.K. (1978). Language and Social Semiotics: The Social Interpretation of Language and Meaning. London: Edward Arnold. 
Hammar, Roberth Kurniawan Ruslak. (2017). Penata Ruang Berbasis Kearifan Lokal. Yogyakarta: Calpulis.

Kamarusdiana. (2019). Studi Etnografi dalam Kerangka Masyarakat dan Budaya. (Online) Vol 6, No 2 (http:/ /journal.uinjkt.ac.id/index.php/salam/

Article/view/10975\&ved=2ahUKEwjfpazag4vjAHUJL48KHVTIC2Cqfja

EgQIBXACusg). Diakses 28 Juni 2021.

Koentjaraningrat. (2015). Pengantar Ilmu Antropologi. Jakarta: Rineka Cipta.

Kramsch, C. (2001). Language and culture. Oxford: Oxford University Press.

Laelasari dan Nurlailah. (2008). Kamus Istilah Sastra. Cetakan kedua. Bandung: Nuansa Aulia.

Ratna, Nyoman Kutha. (2011). Antropologi Sastra. Yogyakarta: Pustaka Pelajar.

Ratna, Nyoman Kutha. (2015). Teori, Metode, dan Teknik Penelitian Sastra. Yogyakarta: Pustaka Pelajar.

Rampan, Korrie Layun. (2015). Api Awan Asap. Cetakan kedua. Jakarta:Grasindo.

Salim, Munir. (2016). Adat Sebagai Budaya Kearifan Lokal Untuk Memperkuat Eksistensi Adat Ke Depan. (Online) Vol 5, No 2. (http://journal.uin-alauddin Ac.id/index.php/al_daulah/article/48/4336). Diakses 28 Juni 2020.

Sembiring, A. et al. (2019). Character Formation Based on North Sumatra Local Wisdom Through Orchestral Learning in Music Education Study Program, Universitas Negeri Medan. Budapest International Research and Critics Institute-Journal (BIRCI-Journal). P. 315-325.

Semi, M. Atar. (2012). Metode Penelitian Sastra.Bandung: CV Angkasa

Sulistyowati, Endang dan Taryad Tarman Effendi. (2018). Kajian Prosa Fiksi. Banjarbaru: Scripta Cendakia.

Sufia, Rohana, et al. (2016). Kearifan Lokal dalam Melestarikan Lingkungan Hidup (Studi Kasus Mayarakat Adat Desa Kemiren Kecamatan Glagah Kabupaten Banyuwangi). (Onlne). Vol $\quad$ 1, No 4.(http://journal.um.ac.id/ Index.php/jptpp/article/viewFile/6234/2663). Diakses 5 Juli 2020.

Zaidan, Abdul Rozak, et al. (2007). Kamus Istilah Sastra. Jakarta: Balai Pustaka.Journal of Scientech Research, 3(2), 197-203. 